\title{
ORIENTASI BERUSAHATANI DI DESA TONSEWER KECAMATAN TOMPASO BARAT KABUPATEN MINAHASA
}

\author{
Megawati Sumilat \\ Melsje Y. Memah \\ Nordy F. L. Waney
}

\begin{abstract}
The purpose of the study was to find out the orientation of farming in Tonsewer Village, West Tompaso Sub-district, Minahasa Regency. This research was conducted for five months, from November 2017 to March 2018, from preparation to formulation of research reports. Research site in Tonsewer Village, West Tompaso Sub-district, Minahasa Regency. This study uses primary data and secondary data. Primary data was obtained from interview of 72 respondents using a questionnaire. Secondary data was obtained from the Office of the Tonsewer Village in the West Tompaso Sub-district, Minahasa Regency. The method of determining the sample in this study using the simple random sampling method using Slovin formula. The results showed that based on the orientation criteria of land input farming, it was commercially oriented because $>65 \%$ of the land was self-owned, the workforce was commercially oriented because $>65 \%$ of farmers paid for outside labor and farm output was commercially oriented because $>65 \%$ of the farm selling, so it can be concluded that farmers in Tonsewer Village are commercially oriented.
\end{abstract}

Keywords: farm orientation, Tonsewer Village, West Tompaso Sub-district, Minahasa Regency

\begin{abstract}
ABSTRAK
Tujuan Penelitian yaitu mengetahui orientasi usahatani di Desa Tonsewer Kecamatan Tompaso Barat Kabupaten Minahasa. Penelitian ini dilaksanakan selama lima bulan yaitu dari bulan November 2017 sampai dengan bulan Maret 2018, mulai dari persiapan sampai penyusunan laporan penelitian. Tempat penelitian di Desa Tonsewer Kecamatan Tompaso Kabupaten Minahasa. Penelitian ini menggunakan data primer dan data sekunder. Data primer diperoleh dari wawancara pada 72 responden dengan menggunakan kuesioner. Data sekunder diperoleh dari Kantor Desa Tonsewer. Metode penentuan sampel dalam penelitian ini menggunakan metode simple random sampling dengan menggunakan rumus Slovin. Hasil Penelitian menunjukkan bahwa berdasarkan kriteria orientasi usahatani input lahan sudah berorientasi komersial karena $>65 \%$ lahan milik sendiri, tenaga kerja sudah berorientasi komersial karena $>65 \%$ petani mengupah tenaga kerja dari luar keluarga dan output usahatani sudah berorientasi komersial karena $>65 \%$ hasil usahatani di jual, jadi dapat di simpulkan bahwa petani di Desa Tonsewer sudah berorientasi komersial.
\end{abstract}

Kata kunci: orientasi usahatani, Desa Tonsewer, Kecamatan Tompaso Barat, Kabupaten Minahasa

Agrisosioekonomi:

Jurnal Transdisiplin Pertanian (Budidaya Tanaman, Perkebunan, Kehutanan, Peternakan, Perikanan), Sosial dan Ekonomi 


\section{PENDAHULUAN}

\section{Latar Belakang}

Pertanian dalam arti sempit adalah usaha atau kegiatan bercocok tanam. Sedangkan dalam arti luas pertanian adalah segala kegiatan manusia yang meliputi kegiatan bercocok tanam, perikanan, peternakan dan kehutanan. Terkait dengan ini, dikenal pula istilah petani (farmer) dan usaha tani (farming). Petani adalah penyelenggara usahatani. Usahatani (farming) adalah sekumpulan kegiatan yang dilakukan dalam budidaya (tumbuhan maupun hewan). Obyek pertanian meliputi budidaya tanaman (termasuk tanaman pangan, hortikultura, dan perkebunan), kehutanan, peternakan, dan perikanan (Laksana, 2013) Peranan sektor pertanian dalam pembangunan ekonomi sangat penting karena sebagian besar anggota masyarakat di Indonesia menggantungkan hidupnya pada sektor tersebut (Soekartawi, 1994).

Usahatani tersebut bukan berasal dari keajaiban, tetapi hasil dari kerja keras dan efisiensi oleh banyak orang dalam suatu sistem yang mencakup kegiatan-kegiatan atas bahan masukan (input), produksi (farm), pengolahan (proccesing), dan pemasaran bahan pangan (output factor).

Kecenderungan ini terus berlanjut sehingga keberadaan sektor agribisnis menjadi semakin penting karena tidak saja bertanggung jawab untuk menyediakan berbagai jenis dan jumlah bahan input yang tepat, tetapi juga bertanggung jawab terhadap bauran pemasaran (marketing mix) yang tepat untuk produk, pada saat tersebut produk bergerak melalui sistem pengolahan bahan pangan sampai dengan ke konsumen terakhir (Firdaus, 2008).

Desa Tonsewer kegiatan bertani telah di lakukan sejak lama dan turun temurun oleh masyarakat yang mayoritas bekerja di bidang pertanian. Sejak dulu para petani di Desa Tonsewer melakukan kegiatan berusahatani mereka hanya dengan menggunakan teknikteknik usahatani dan menggunakan peralatan pertanian secara tradisional.

Berkembangnya teknologi di bidang pertanian, mendorong para petani untuk lebih mengembangkan cara berusahatani mereka yang lebih maju dan modern dengan menemukan teknik-teknik dalam berusahatani seperti dalam pemilihan bibit, penggunaan pupuk, mengatur kelembapan tanah, metode budidaya, pengolahan dan pengemasan produk, pemasaran serta menggunakan teknologi yang lebih maju. dan semakin berjalannya waktu, sistem pola pertanian dari masa ke masa pun akan terus berkembang menjadi lebih baik, untuk menghasilkan hasil pertanian yang lebih baik pula. Oleh karena itu berdasarkan latar belakang yang telah di kemukakan maka peneliti melakukan penelitian dengan judul "Orientasi Berusahatani Di Desa Tonsewer Kecamatan Tompaso Barat Kabupaten Minahasa".

\section{Sejarah Kemajuan Masyarakat dan Pertanian}

Menurut F. list, Roscher (1858) Tiaptiap masyarakat itu dalam bergeraknya dapat melalui tingkatan-tingkatan sebagai berikut.

Pada tingkatan pertama manusia hidup secara mengembara mencari makanan. Mereka hidup dari pemberian alam saja, yaitu buah-buahan, daun-daunan, dan ubi-ubian yang tumbuh liar di ladang dan di hutan-hutan, ikan di perairan dan binatang yang di jinakan seperti ular, cacing, keong dan sebagainya.

Usaha mencari makan ini dilakukan bersama-sama (dalam persekutuan), sebab manusia itu sejak permulaannya tidak pernah hidup seseorang akan tetapi dalam persekutuannya terdapat pembagian pekerjaan. Tingkatan masyarakat semacam ini oleh E. Hahn (1914) disebut tata rumah tangga mengumpulkan (sammelwietschaft), sedangkan Moszkowski menamakannya tata rumah tangga yang mempunyai corak memeras kekayaan alam secara tidak teratur.

Pada tingkatan kedua mulailah orang menghasilkan barang, yakni dengan pemeliharaan ternak. Dalam tingkatan penghidupan tersebut, orang masih belum melepaskan penghidupannya secara mengembara. Penghidupan mengembara tersebut baru di lepaskan, tatkala orang mulai menginjak zama tingkatan yang ketiga.

Pada tingkatan yang ketiga, orang terutama menggantungkan penghidupannya 
kepada tanah yang ditanaminya. Penghidupan secara mengembara di tinggalkan dimana ia becocok tanam, disitu ia duduk tetap. Dengan ini berdirilah masyarakat yang pertama yaitu dusun atau desa.

Lama-kelamaan berubahlah pokok dasar penghidupan orang itu. Penghidupan yang di sandarkan pada pertanian diperluas. Akhirnya tercapailah tingkatan penghidupan, dimana manusia menyandarkan kemakmurannya pada pertanian dan perindustrian-perniagaan. Dan tingkatan inilah yang dapat kita namakan tingkatan keempat.

Demikian dalam garis besarnya pendapat List tentang sejarah kemajuan manusia.

\section{Perusahaan Pertanian}

Untuk mengadakan analisa ekonomi yang berarti, pertanian Indonesia telah dibagi dua yaitu usahatani pertanian rakyat (small holder) dan perusahaan pertanian. Perusahaan pertanian sebagai lawan pertanian rakyat adalah perusahaan pertanian untuk memproduksi hasil tertentu dengan sistem pertanian seragam di bawah manajemen yang terpusat dengan menggunakan bebagai metode ilmiah dan teknik pengolahan yang efisien. Di Indonesia perusahaan-perusahaan pertanian yang penting dan yang sudah mempunyai sejarah yang lama adalah perkebunan (plantation), yang mengusahakan tanah-tanah yang luas berdasarkan hak-hak perusahaan tertentu. Keseluruhan tanah dan bangunan pabrik serta perumahan pegawai, buruh dan pimpinan perkebunan pada satu tempat tertentu disebut estate. Di samping perkebunan, perusahaan-perusahaan pertanian dapat berbentuk perusahaan eksploitasi hutan, perusahaan peternakan atau perikanan (laut dan darat) yang kesemuanya mempunyai tujuan utama untuk mendapatkan keuntungan sebesar-besarnya. Perusahaan-perusahaan pertanian dalam arti luas ini dapat berstatus perusahaan swasta nasional, joint venture atau perusahaan asing tergantung pada pemilik sumber permodalannya.

\section{Sejarah dan Perkembangan Usahatani}

\section{Sejarah Usahatani}

Sejarah pertanian dimulai dari adanya pembagian tugas antara laki-laki dan perempuan. Perempuan menerima kodrat untuk melahirkan sekaligus bertugas memelihara anak-anak, sedangkan laki-laki melakukan kegiatan berburu. Oleh karena kodratnya dan tugasnya memelihara anak-anak yang dilahirkan maka perempuan secara langsung yang menyediakan makanan. Kegiatan menyediakan makanan dimulai dengan mengumpulkan berbagai tanaman, umbiumbian, jamur, dan binatang kecil. Oleh karena kecintaannya akan kehidupan maka perempuan belajar juga menanam biji-bijian, umbi-umbian, dan memelihara ternak sehingga akhirnya mengenal berbagai jenis tanama pangan yang dibutuhkan untuk keberlangsungan hidup. Kegiatan tersebut yang sekarang ini dikenal dengan sistem bercocok tanaman (Suratiyah, 1983). Dalam sejarah juga tercatat bahwa perempuan yang membuat berbagai alat untuk untuk menunjang kehidupannya dan kesehatanya sendiri sehingga perempuanlah yang menciptakan tikar, periuk, tembikar, serta menemukan berbagai tanaman obat dan meramunya begitu juga dengan memintal serta untuk pakaian. Dengan demikian, perempuan juga dinyatakan sebagai pembangun kultur pertama (Suratiyah, 1983).

\section{Orientasi Usahatani}

Pengelolaan usahatani diperlukan unsurunsur pokok yang merupakan faktor utama dalam usahatani. Unsur-unsur pokok tersebut sering disebut faktor produksi, atau input. Input adalah semua yang dimasukkan ke dalam proses produksi, misalnya tanah yang digunakan, tenaga kerja (baik keluarga maupun diluar keluarga), kegiatan perencanaan manajemen yang dilakukan, saprodi yang digunakan dan lain-lain. Output adalah proses yang mengkombinasikan faktor-faktor produksi pertanian untuk menghasilkan produksi pertanian.

Menurut Bachtiar Rivai (1980), usahatani merupakan organisasi dari alam, tenaga kerja dan modal yang ditujukan kepada 
produksi dilapangan pertanian, oleh seseorang atau sekelompok orang, segolongan sosial baik yang terikat genologis, politis, maupun teritorial sebagai pengelolanya.

Fadholi Hernanto (1989), beranggapan bahwa dari definisi usahatani oleh Bachtiar Rivai dapat diturunkan empat unsur pokok yang selalu ada pada suatu usahatani. Keempat unsur pokok ini sering disebut dengan faktor-faktor produksi, yaitu :
a. Tanah
b. Tenaga Kerja
c. Modal
d. Manajemen

Sistem usahatani melibatkan berbagai kegiatan pengambilan keputusan petani untuk melakukan usahatani. Pengambilan keputusan ini sangat dipengaruhi oleh berbagai macam faktor pembentuk sistem pertanian. Model Sistem Pertanian sebagai suatu sistem dalam hal ini merupakan tipe pertanian yang ditentukan khusus oleh kondisi lingkungan alam dan proses sosial ekonomi tertentu yang mencakup cara- cara, karakteristik, orientasi, serta efek (hasil) usahatani tertentu.

\section{Rumusan Masalah}

Berdasarkan latar belakang yang di telah di uraikan tersebut, maka di kemukakan rumusan masalah penelitian, yaitu: bagaimana orientasi petani dalam berusahatani di Desa Tonsewer Kecamatan Tompaso barat.

\section{Tujuan Penelitian}

Mengetahui orientasi petani dalam berusahatani di Desa Tonsewer Kecamatan Tompaso Barat Kabupaten Minahasa.

\section{Manfaat Penelitian}

1. Bagi peneliti, penelitian ini merupakan syarat guna memperoleh derajat sarjana pertanian di fakultas pertanian, Universitas Sam Ratulangi, serta bagi mahasiswa lain penelitian ini dapat digunakan untuk menambah wawasan dan pengetahuan terutama berkaitan dengan orientasi usahatani.

2. Bagi pihak lain penelitian ini diharapkan dapat memberikan sumbangan pemikiran, tambahan informasi yang bermanfaat dapat digunakan sebagai acuan untuk penelitian lebih lanjut.

\section{METODE PENELITIAN}

\section{Lokasi dan Waktu Penelitian}

Penelitian ini dilakukan di Desa Tonsewer kecamatan Tompaso Barat, dilakukan selama 5 bulan terhitung dari bulan November 2017 sampai Maret 2018.

\section{Teknik Pengumpulan Data}

Teknik pengumpulan data dengan tiga cara sebagai berikut: Observasi, Wawancara dan Studi Literarur

\section{Metode Pengambilan Sampel}

Adapun penelitian ini menggunakan rumus Slovin dalam penentuan sampel. Rumus Slovin untuk menentukan sampel adalah sebagai berikut :

$$
n=\frac{N}{1+N(e)^{2}}
$$

Keterangan:

$$
\begin{aligned}
& n=\text { Ukuran sampel/jumlah responden } \\
& \mathrm{N}=\text { Ukuran populasi } \\
& \mathrm{e}=\text { Presentase kelonggaran ketelitian }
\end{aligned}
$$
sebagai berikut:

Nilai e $=0,1(10 \%)$ untuk populasi dalam jumlah besar

Nilai e $=0,2(20 \%)$ untuk populasi dalam jumlah kecil.

Jadi rentang sampel yang dapat diambil dari teknik Slovin adalah antara 10$20 \%$ dari populasi penelitian.

Jumlah Populasi dalam penelitian ini adalah seluruh petani yang ada di desa Tonsewer Kecamatan Tompaso Barat Kabupaten Minahasa, yang berjumlah 251 keluarga. Maka untuk mengetahui sampel penelitian, dengan perhitungan sebagai berikut:

$$
\begin{aligned}
n & =\frac{251}{1+251(0.1)^{2}} \\
n & =\frac{251}{3 .} \\
n & =71.5099715 \text { di sesuaikan oleh peneliti } \\
& \text { menjadi } 72 \text { responden. }
\end{aligned}
$$




\section{Konsep Pengukuran Variabel} ini adalah :

Variabel yang diukur dalam penelitian

A. Input Usahatani

1. Lahan: luas lahan pertanian yang dimiliki dan/atau diusahakan petani

2. Tenaga Kerja: jumlah tenaga kerja keluarga dan tenaga kerja luar keluarga yang terlibat dalam kegiatan usahatani

3. Modal: jumlah modal uang sendiri dan yang bersumber dari luar (pinjaman) yang digunakan sebagai modal dalam kegiatan usahatani dihitung satu musim tanam

B. Output Usahatani

1. Produksi: jumlah produksi atau hasil pertanian per musim tanam

C. Harga: harga output usahatani/hasil pertanian yang diusahakan petani pada saat panen.

D. Pendapatan: penerimaan hasil usahatani dikurangi pengeluaran usahatani dalam satu musim tanam.

E. Orientasi Usaha

1. Input: persentasi input (TK, Modal, Lahan) milik sendiri dan persentasi input dari luar (dibeli/disewa/diupah).

2. Output: persentasi output usahatani yang dikonsumsi keluarga dan persentase output yang dijual.

\section{Konsep Analisis Data}

Metode analisis yang digunakan dalam penelitian ini adalah metode analisis deskriptif, dimana metode analisis ini mendeskripsikan setiap data yang diambil. Menurut (Koentjaraningrat, 1993) metode kualitatif dengan desain deskriptif, adalah penelitian yang memberi gambaran secara cermat mengenai individu atau kelompok tertentu tentang keadaan dan gejala yang terjadi. Pengamatan yang diarahkan untuk memperoleh fakta-fakta yang di analisis menggunakan metode analisis deskriptif, data hasil wawancara diolah dan dibuat tabulasi, kemudian hasilnya di interprestasikan sesuai dengan tujuan yang ingin dicapai.
Orientasi Usahatani
Kriteria yang digunakan untuk melihat/menentukan orientasi usahatani Holtikultura di Desa Tonsewer adalah sebagai berikut :

Input $<35 \%$ (Subsisten)

$35 \%-65 \%$ (Semi komersial)

$>65 \%$ (Komersial)

Output $<35 \%$ dijual (Subsisten)

35\%-65\% dijual (Semi komersial)

$>65 \%$ dijual (Komersial)

Kriteria tersebut hanya berdasarkan perkiraan saja, belum ada pustaka yang menjelaskannya secara spesifik.

\section{HASIL DAN PEMBAHASAN}

\section{Gambaran Umum Lokasi Penelitian}

Gambaran umum tentang Desa Tonsewer meliputi sejarah, letak geografi dan batas-batas wilayah, kondisi penduduk menurut jenis kelamin, tingkat pendidikan, mata pencaharian dan agama.

\section{Letak Geografi dan Batas-batas Wilayah Desa Tonsewer}

Desa Tonsewer memiliki luas wilayah sebesar 132 Ha. Adapun batas-batas wilayah dari Desa Tonsewer adalah sebagai berikut :

Sebelah Utara: Desa Sendangan, sebelah Selatan: Desa Tonsewer Selatan, sebelah Timur: Desa Toure dan sebelah Barat: Desa Pinabetengan.

Penduduk Menurut Jenis Kelamin

Penduduk Menurut Jenis yang ada di Desa Tonsewer dapat dilihat pada Tabel 1.

Tabel 1. Jumlah Penduduk Menurut Jenis Kelamin

\begin{tabular}{|c|c|c|}
\hline $\begin{array}{c}\text { Jenis } \\
\text { Kelamin }\end{array}$ & $\begin{array}{c}\text { Jumlah } \\
\text { (Jiwa) }\end{array}$ & Persentase (\%) \\
\hline Laki-laki & 478 & 51,45 \\
\hline Perempuan & 451 & 48,55 \\
\hline Jumlah & 929 & 100 \\
\hline
\end{tabular}

Sumber : Data Statistik Desa Tonsewer, 2015

Berdasarkan rekapitulasi, penduduk Desa Tonsewer berjumlah 929 jiwa, yang terdiri dari laki-laki 478 jiwa dan perempuan 451 jiwa. Berikut ini Tabel 2 berdasarkan jenis kelamin 
Tabel 2. Penduduk Menurut Mata Pencaharian

\begin{tabular}{|c|c|c|c|}
\hline No & Mata Pencaharian & Jumlah & Persentase $(\%)$ \\
\hline 1 & Petani & 251 & 28,01 \\
\hline 2 & Pelajar & 223 & 24,89 \\
\hline 3 & Ibu Rumah Tangga & 175 & 19,53 \\
\hline 4 & Belum Bekeria & 81 & 9,04 \\
\hline 5 & Belum Bekerja & 30 & 3,34 \\
\hline 6 & Pedagang Keliling & 30 & 3,34 \\
\hline 7 & Tidak Mempunyai Pekerjaan & 22 & 2,46 \\
\hline 8 & Tetap & 17 & 1,90 \\
\hline 9 & Wiraswasta & 17 & 1,90 \\
\hline 10 & Pegawai Negeri Sipil & 10 & 1,11 \\
\hline 11 & Buruh Harian Lepas & 6 & 0,67 \\
\hline 12 & Guru Swasta & 6 & 0,67 \\
\hline 13 & Peternak & 6 & 0,67 \\
\hline 14 & Tukang Kayu & 4 & 0,44 \\
\hline 15 & Pensiunan & 4 & 0,44 \\
\hline 16 & Sopir & 3 & 0,33 \\
\hline 17 & Pedagang Barang Kelontong & 2 & 0,22 \\
\hline 18 & Pengusaha & 1 & 0,11 \\
\hline 19 & Montir & 1 & 0,11 \\
\hline 20 & Ahli Pengobatan alternative & 1 & 0,11 \\
\hline 21 & TNI & 1 & 0,11 \\
\hline 22 & Polri & 1 & 0,11 \\
\hline 23 & Arsitektur & 1 & 0,11 \\
\hline 24 & Karyawan Perusahaan Swasta & 1 & 0,11 \\
\hline 25 & Karyawan Perusahaan Pemerintah & 1 & 0,11 \\
\hline \multirow[t]{4}{*}{26} & Konsultan Manajemen dan Teknis & 1 & 0,11 \\
\hline & Tukang Batu & & \\
\hline & Pembantu Rumah tangga & & \\
\hline & Jumlah & 896 & 100 \\
\hline
\end{tabular}

Berdasarkan Tabel 2 menunjukkan jenis mata pencaharian penduduk Desa Tonsewer dengan presentase masing-masing jenis mata pencaharian. Dari Tabel 2 dapat dilihat bahwa jumlah mata pencaharian sebagai petani adalah yang paling banyak dengan jumlah 238 orang dengan presentase $26,96 \%$.

\section{Karakteristik Responden}

\section{Umur Responden}

Umur petani responden yang ada di Desa Tonsewer dapat dilihat pada Tabel 3.

\begin{tabular}{lccc}
\multicolumn{4}{l}{ Tabel 3. Klasifikasi Responden Menurut Kelompok Umur } \\
\hline No & Umur & Jumlah Responden & Persentase (\%) \\
\hline 1 & $\leq 30$ & 7 & 9,72 \\
2 & $31-40$ & 15 & 20,83 \\
3 & $41-50$ & 22 & 30,56 \\
4 & $51-60$ & 20 & 27,78 \\
5 & $\geq 61$ & 8 & 11,11 \\
\hline & Jumlah & 72 & 100 \\
\hline
\end{tabular}

Tabel 3, menunjukan jumlah dan presentase petani responden Desa Tonsewer berdasarkan umur. Hasil yang di tunjukkan pada tabel 3 menjelaskan bahwa 7 responden mempunyai umur $\leq 30$ dan merupakan presentase terkecil yaitu $9,72 \%$, sedangkan 22 responden yang berumur antara 41-50 merupakan jumlah terbanyak dengan presentase $20,83 \%$.

\section{Tingkat Pendidikan Responden}

Tingkat pendidikan petani responden Desa Tonsewer dapat dilihat pada Tabel 4.

Tabel 4. Responden Menurut Tingkat Pendidikan

\begin{tabular}{cccc}
\hline No & $\begin{array}{c}\text { Tingkat } \\
\text { Pendidikan }\end{array}$ & $\begin{array}{c}\text { Jumlah } \\
\text { Responden }\end{array}$ & $\begin{array}{c}\text { Persentase } \\
(\boldsymbol{\%})\end{array}$ \\
\hline 1 & SD & 33 & 45,83 \\
2 & SMP & 17 & 23,61 \\
3 & SMA & 22 & 30,56 \\
\hline & Jumlah & 72 & 100 \\
\hline
\end{tabular}

Tabel 4, menjelaskan bahwa sebagian besar responden memiliki tingkat pendidikan SD yaitu 33 orang dengan persentase $45,83 \%$, tingkat pendidikan SMP merupakan tingkat pendidikan paling sedikit karena hanya berjumlah 17 orang dengan persentase $23,61 \%$, dan tingkat pendidikan SMA yangberjumlah 22 orang dengan persentase $30,56 \%$ merupakan tingkat pendidikan ke-2 terbanyak setelah tingkat pendidikan SD.

\section{Jumlah Tanggungan Responden}

$$
\text { Jumlah tanggungan }
$$

yang dimaksudkan dalam penelitian ini adalah anggota keluarga yang statusnya belum berkeluarga (single) dan masih di tanggung atau bergantung pada responden (Koibur, 2017). Jumlah anggota keluarga yang menjadi tanggungan responden dapat dilihat pada Tabel 5.

Tabel 5. Jumlah Tanggungan Responden

\begin{tabular}{cccc}
\hline No & $\begin{array}{c}\text { Jumlah } \\
\text { Tanggungan } \\
\text { (Orang) }\end{array}$ & $\begin{array}{c}\text { Jumlah } \\
\text { (Responden) }\end{array}$ & $\begin{array}{c}\text { Persentase } \\
(\boldsymbol{\%})\end{array}$ \\
\hline 1 & $\leq 3$ & 38 & 52,78 \\
2 & $\geq 4$ & 34 & 47,22 \\
\hline & Total & 72 & 100 \\
\hline
\end{tabular}

Tabel 5, menunjukkan bahwa dari 72 orang petani responden, 38 petani memiliki jumlah tanggungan $\leq 3$ orang dan 34 petani lainya memiliki jumlah tanggungan $\geq 4$ orang. Hal ini menunjukkan bahwa semua petani yang menjadi responden memiliki beberapa jumlah tanggungan yang harus di tanggung oleh responden. 


\section{Orientasi usahatani Desa Tonsewer}

\section{Luas Lahan Petani}

Tanah merupakan salah satu faktor produksi dan juga sebagai pabrik penghasil bagi sektor pertanian di mana proses input berlangsung sampai tahap output. Luas lahan pertanian petani responden yang ada di Desa Tonsewer dapat dilihat pada Tabel 6 .

Tabel 6. Luas Lahan Petani Responden

\begin{tabular}{cccc}
\hline No. & $\begin{array}{c}\text { Luas Lahan } \\
\left(\mathbf{M}^{\mathbf{2}}\right)\end{array}$ & $\begin{array}{c}\text { Jumlah } \\
(\text { Responden) }\end{array}$ & $\begin{array}{c}\text { Persentase } \\
(\boldsymbol{\%})\end{array}$ \\
\hline 1 & $\leq 3.000$ & 3 & 4,17 \\
2 & $3.100-5.000$ & 62 & 86,11 \\
3 & $\geq 5.100$ & 7 & 9,72 \\
\hline & Total & 72 & 100
\end{tabular}

Hasil penelitian pada Tabel 6, menunjukkan bahwa dari 72 petani responden terdapat 3 petani yang memiliki luas lahan $\leq$ $3.000 \mathrm{Ha}$ dan juga merupakan luas lahan dengan presentase rendah yaitu 4,17\%, 62 orang petani memiliki luas lahan antara $3.100-5.000$ Ha dan juga merupakan presentase tertinggi yaitu $86,11 \%$, serta 7 orang petani memiliki luas lahan $\geq 5.100$ dengan presentase $9,72 \%$.

\section{Status Lahan Petani}

Lahan pertanian sangat berhubungan erat dengan petani, karena lahan pertanian merupakan media tanam yang digunakan para petani untuk bercocok tanam guna memperoleh hasil panen dan juga menjadi salah satu sumber penghasil bagi petani. Hasil penelitian yang diperoleh dari 72 petani responden yang berada di Desa Tonsewer tentang status kepemilikan lahan secara rinci dapat dilihat pada Tabel 7.

Tabel 7. Status Lahan Petani Responden

\begin{tabular}{llcc}
\hline No. & Status Lahan & $\begin{array}{c}\text { Jumlah } \\
\text { (Responden) }\end{array}$ & $\begin{array}{c}\text { Persentase } \\
(\boldsymbol{\%})\end{array}$ \\
\hline 1 & Milik Sendiri & 58 & 80,55 \\
2 & Sewa & 10 & 13,89 \\
3 & Garap & 4 & 5,56 \\
\hline & Jumlah & 72 & 100 \\
\hline
\end{tabular}

Berdasarkan hasil penelitian seperti yang terlihat pada Tabel 7, menunjukkan bahwa petani yang memiliki lahan milik sendiri adalah sebanyak 58 petani dengan presentase $80,55 \%$, petani yang tidak memiliki lahan dan menyewa lahan adalah berjumlah 10 petani $(13,89 \%)$ dan
4 petani $(5,56 \%)$ merupakan petani penggarap yang di mana hasilnya akan dibagi dengan pemilik lahan sesuai kesepakatan yang telah disepakati bersama. Hal ini menujukkan bahwa rata-rata petani responden yang ada di Desa Tonsewer memiliki lahan milik sendiri.

\section{Biaya Sewa Lahan}

Penelitian yang dilakukan di Desa Tonsewer menunjukkan bahwa dari 72 petani responden terdapat 10 petani yang tidak memiliki lahan dan harus menyewa lahan untuk bertani. Biaya sewa lahan dari petani dapat dilihat pada Tabel 8.

\section{Tabel 8. Biaya Sewa Lahan}

\begin{tabular}{cccc}
\hline No. & $\begin{array}{c}\text { Biaya Sewa } \\
\text { Lahan }\end{array}$ & $\begin{array}{c}\text { Jumlah } \\
\text { (Responden) }\end{array}$ & $\begin{array}{c}\text { Persentase } \\
(\mathbf{\%})\end{array}$ \\
\hline 1 & $\leq 1.500 .000$ & 3 & 30 \\
2 & $\geq 2.000 .000$ & 7 & 70 \\
\hline & Jumlah & 10 & 100 \\
\hline
\end{tabular}

Tabel 8, menunjukkan bahwa dari 72 petani responden hanya 10 orang petani yang mengeluarkan biaya sewa lahan selama 1 tahun. 3 orang petani mengeluarkan biaya sewa lahan $\leq$ Rp.1.500.000 dan 7 orang petani lainya menyewa lahan dengan biaya sewa $\geq$ Rp.2.000.000.

\section{Lama Bertani}

Pengalaman petani biasanya dilihat dari seberapa lama seorang petani melakukan atau menjalankan kegiatan usahatani. Pengalaman atau lamanya bertani yang diperoleh dari penelitian di Desa Tonsewer terhadap 72 petani responden dapat dilihat pada Tabel 9 sebagai berikut.

Tabel 9. Lama Bertani

\begin{tabular}{cccc}
\hline No. & $\begin{array}{c}\text { Lama Bertani } \\
\text { (Tahun) }\end{array}$ & $\begin{array}{c}\text { Jumlah } \\
\text { (Responden) }\end{array}$ & $\begin{array}{c}\text { Persentase } \\
(\boldsymbol{\%})\end{array}$ \\
\hline 1 & $\leq 10$ & 16 & 22,22 \\
2 & $11-20$ & 21 & 29,17 \\
3 & $21-30$ & 21 & 29,17 \\
4 & $\geq 30$ & 14 & 19,44 \\
\hline & Jumlah & 72 & 100 \\
\hline
\end{tabular}

Lamanya berusahatani yang dilakukan oleh para petani responden berbeda-beda. Tabel 9, menunjukkan bahwa 16 petani memiliki pengalaman atau lamanya bertani $\leq 10$ tahun dengan presentase $22,22 \%$, lamanya bertani 
antara 11 - 20 tahun dan 21 - 30 tahun memiliki jumlah petani serta presentase yang sama yaitu 21 petani responden dengan presentase $29,17 \%$, dan lama bertani $\geq 30$ terdapat 14 petani dengan presentase $19,44 \%$.

\section{Sumber Bibit}

Sebagian besar petani yang berada di Desa Tonsewer, memperoleh bibit dengan cara membeli langsung pada petani yang telah memanen hasil panen mereka. Sumber bibit yang diperoleh petani responden secara lengkap dapat dilihat pada Tabel 10.

Tabel 10. Sumber Bibit

\begin{tabular}{clcc}
\hline No. & Sumber & $\begin{array}{c}\text { Jumlah } \\
\text { (Responden) }\end{array}$ & $\begin{array}{c}\text { Persentase } \\
(\boldsymbol{\%})\end{array}$ \\
\hline 1 & Beli & 68 & 94,44 \\
2 & Bantuan & 3 & 4,17 \\
3 & Milik Sendiri & 1 & 1,39 \\
\hline & Jumlah & 72 & 100 \\
\hline
\end{tabular}

Tabel 10, menunjukkan bahwa dari 72 petani responden terdapat 68 petani yang membeli bibit dengan presentase tertinggi yaitu $94,44 \%, 3$ petani mendapat bantuan bibit dengan presentase $4,17 \%$, serta 1 orang petani yang memiliki bibit sendiri dengan presentase terendah yaitu $1,39 \%$.

\section{Jumlah Bibit}

Salah satu penentu hasil produksi atau panen yang dihasilkan oleh petani adalah seberapa banyak bibit yang dimiliki. Jumlah bibit dari petani responden secara lengkap dapat dilihat pada Tabel 11.

Tabel 11. Jumlah Bibit

\begin{tabular}{cccc}
\hline No. & $\begin{array}{c}\text { Jumlah } \\
\text { Bibit (Kg) }\end{array}$ & $\begin{array}{c}\text { Jumlah } \\
\text { (Responden) }\end{array}$ & $\begin{array}{c}\text { Persentase } \\
(\%)\end{array}$ \\
\hline 1 & $\leq 200$ & 55 & 76,39 \\
2 & $201-400$ & 9 & 12,5 \\
3 & $401-600$ & 6 & 8,33 \\
4 & $\geq 601$ & 2 & 2,78 \\
\hline & Jumlah & 72 & 100 \\
\hline
\end{tabular}

Hasil penelitian jumlah bibit terhadap 72 petani responden pada Tabel 11, menunjukkan bahwa 55 petani memiliki jumlah bibit $\leq 200$ dengan presentase $76,39 \%$ dan merupakan presentase terbanyak, sedangkan jumlah bibit $\geq$ 601 yang merupakan bibit terbanyak hanya terdapat 2 orang petani dengan presentase $2,78 \%$.

\section{Harga Bibit}

Harga merupakan hasil akhir dari kesepakan yang telah disepakati antara pihak produsen dengan pihak konsumen guna melancarkan proses jual beli antara kedua bela pihak. Tinggi rendahnya harga jual bibit yang ada di Desa Tonsewer tergantung pada seberapa banyak jumlah bibit yang dibeli. Harga jual bibit dapat dilihat pada Tabel 12 .

Tabel 12. Harga Bibit

\begin{tabular}{cccc}
\hline No. & $\begin{array}{c}\text { Harga Bibit } \\
(\mathbf{R p})\end{array}$ & $\begin{array}{c}\text { Jumlah } \\
\text { (Responden) }\end{array}$ & $\begin{array}{c}\text { Persentase } \\
(\mathbf{\%})\end{array}$ \\
\hline 1 & $<20.000$ & 34 & 50,00 \\
2 & $20.000-40.000$ & 33 & 48,53 \\
3 & $>40.000$ & 1 & 1,47 \\
\hline & Jumlah & 68 & 100 \\
\hline
\end{tabular}

Berdasarkan rincian harga jual bibit pada Tabel 12, menunjukkan bahwa sebagian besar dari petani responden membeli bibit. 38 petani membeli bibit dengan harga < Rp.20.000, 33 petani membeli bibit dengan haraga antara Rp.20.000 - Rp.40.000, dan 1 petani membeli bibit dengan haraga > Rp.40.000. Berdasarkan tabel 12 , dapat dilihat bahwa hanya 68 petani yang membeli bibit dan sisah dari pada itu 3 petani mendapatkan bantuan bibit serta 1 petani memiliki bibit milik sendiri.

\section{Tenaga Kerja}

\section{Jumlah Tenaga Kerja dalam Keluarga}

Menurut Subri (2003), tenaga kerja adalah penduduk usia kerja (berusia 15-64 tahun) atau jumlah seluruh penduduk dalam suatu negara yang dapat memproduksi barang dan jasa jika ada permintaan terhadapmereka, dan jika mereka mau berpartisipasi dalam aktivitas tersebut. Jumlah tenaga kerja dalam keluarga dapat dilihat pada Tabel 13.

Tabel 13. Jumlah Tenaga Kerja dalam Keluarga

\begin{tabular}{cccc}
\hline No. & $\begin{array}{l}\text { Tenaga Kerja } \\
\text { (Orang) }\end{array}$ & $\begin{array}{c}\text { Jumlah } \\
\text { (Responden) }\end{array}$ & $\begin{array}{c}\text { Persentase } \\
(\boldsymbol{\%})\end{array}$ \\
\hline 1 & $1-2$ & 63 & 87,50 \\
2 & $3-4$ & 9 & 12,50 \\
\hline & Jumlah & 72 & 100 \\
\hline
\end{tabular}

Tabel 13, menunjukkan bahwa keluarga juga ikut serta mengambil bagian sebagai tenaga kerja. Jumlah tenaga kerja dalam keluarga yang dapat dilihat pada Tabel 13 yaitu 
63 petani responden memiliki jumlah tenaga kerja dalam keluarga antara 1 - 2 orang dengan presentase $87,50 \%$ dan 9 petani dengan presentase $12,50 \%$ yang memiliki $3-4$ orang tenaga kerja dalam keluarga.

\section{Jumlah Tenaga Kerja Luar Keluarga}

Tenaga kerja luar keluarga adalah tenaga kerja yang dipekerjakan oleh petani karena beberapa hal seperti ; tidak adanya tenaga kerja dalam keluarga, kurangnya tenaga kerja selain tenaga kerja dalam keluarga, dan luas lahan bahkan banyaknya hasil panen yang membutuhkan banyak tenaga kerja. Keterangan mengenai tenaga kerja luar keluarga dapat dilihat pada Tabel 14.

\begin{tabular}{cccc}
\multicolumn{4}{c}{ Tabel 14. Jumlah Tenaga Kerja Luar Keluarga } \\
\hline No. & $\begin{array}{c}\text { Tenaga Kerja } \\
\text { (Orang) }\end{array}$ & $\begin{array}{c}\text { Jumlah } \\
\text { (Responden) }\end{array}$ & $\begin{array}{c}\text { Persentase } \\
(\%)\end{array}$ \\
\hline 1 & $\leq 10$ & 51 & 70,83 \\
2 & $11-20$ & 6 & 8,33 \\
3 & $\geq 21$ & 3 & 4,17 \\
4 & Tidak Ada & 12 & 16,67 \\
\hline & Jumlah & 72 & 100 \\
\hline
\end{tabular}

Tabel 14, menunjukkan bahwa tidak semua petani menggunakan tenaga kerja luar keluarga namun dari 72 petani responden 51 petani dengan presentase tertinggi yaitu $70,83 \%$ menggunakan tenaga kerja luar keluarga.

\section{Sumber Modal}

Dalam usaha tani modal merupakan barang ekonomi yang digunakan untuk memperoleh pendapatan dan untuk mempertahankan pendapatan keluarga tani (Warsana, 2007). Sumber modal dari petani responden yang ada di Desa Tonsewer dapat dilihat pada Tabel 15 .

\begin{tabular}{cccc}
\multicolumn{4}{l}{ Tabel 15. Sumber Modal Petani Responden } \\
\hline No. & $\begin{array}{c}\text { Sumber } \\
\text { Modal }\end{array}$ & $\begin{array}{c}\text { Jumlah } \\
\text { (Responden) }\end{array}$ & $\begin{array}{c}\text { Persentase } \\
(\boldsymbol{\%})\end{array}$ \\
\hline 1 & Milik Sendiri & 65 & 90,28 \\
2 & Pinjam & 7 & 9,72 \\
\hline & Jumlah & 72 & 100 \\
\hline
\end{tabular}

\section{Hasil Panen}

Hasil panen atau produksi merupakan salah satu tujuan bagi petani untuk mendapatkan pendapatan yang tinggi. Produksi merupakan hasil yang diperoleh pada saat panen. Hasil panen petani yang ada di Desa Tonsewer dapat dilihat pada Tabel 16.
Tabel 16. Hasil Panen

\begin{tabular}{cccc}
\hline No & $\begin{array}{c}\text { Hasil Panen } \\
(\mathbf{K g})\end{array}$ & $\begin{array}{c}\text { Jumlah } \\
(\text { Responden) }\end{array}$ & $\begin{array}{c}\text { Persentase } \\
(\boldsymbol{\%})\end{array}$ \\
\hline 1 & $<500$ & 42 & 58,33 \\
2 & $500-1.000$ & 17 & 23,61 \\
3 & $>1.000$ & 13 & 18,06 \\
\hline & Jumlah & 72 & 100 \\
\hline
\end{tabular}

Tabel 16, menjelaskan bahwa hasil panen yang diperoleh petani responden berbeda-beda. Hasil panen < 500 merupakan presesntase terbanyak yaitu $58,33 \%$ dengan jumlah petani 42 orang, sedangkan jumlah hasil panen $>1.000$ dengan presentase $18,06 \%$ merupakan presentase paling sedikit yang terdiri dari 13 orang petani. Rata-rata hasil panen yang diperoleh petani responden adalah $816 \mathrm{Kg}$.

Hasil panen yang diperoleh petani di Desa Tonsewer, dibagi menjadi 3 bagian. Bagian pertama yaitu bagian yang akan dijual oleh petani, dimana rata-rata hasil panen yang dijual adalah $708 \mathrm{Kg}$. Rata-rata pendapatan petani ialah Rp.8.691.111 yang diperoleh dari rata-rata penerimaan Rp.12.908.101 dikurangi dengan rata-rata total biaya Rp.4.216.990 dalam satu kali panen. Kedua yaitu bagian yang akan dikonsumsi oleh petani, rata-rata hasil panen yang dikonsumsi petani adalah 12 Kg. Ketiga yaitu hasil panen yang disimpan untuk digunakan sebagai bibit, rata-rata hasil panen yang disimpan adalah $151 \mathrm{Kg}$.

\section{Orientasi Berusahatani di Desa Tonsewer}

Hasil penelitian di Desa Tonsewer tentang perubahan orientasi berusaha tani menunjukan bahwa petani yang ada di Desa Tonsewer memiliki kareteristik yang dilihat dari input dan output usahatani sebagai berikut :

\section{Input Berusahatani}

\section{Lahan}

Status lahan di Desa Tonsewer terdiri dari, lahan milik sendiri, lahan sewa, dan lahan sakap (bagi hasil). Input lahan di Desa Tonsewer dapat di lihat pada Table 17.

Tabel 17. Input Rata-rata Luas Lahan, Lahan Milik Sendiri, Lahan Sewa dan Lahan Garap

\begin{tabular}{c|c|c|c}
\hline $\begin{array}{c}\text { Rata-rata } \\
\text { Luas Lahan }\left(\mathbf{M}^{\mathbf{2}}\right)\end{array}$ & $\begin{array}{c}\text { Lahan Milik } \\
\text { Sendiri }\end{array}$ & $\begin{array}{c}\text { Lahan } \\
\text { Sewa }\end{array}$ & $\begin{array}{c}\text { Lahan } \\
\text { Garap }\end{array}$ \\
\hline 3.830 & $80,55 \%$ & $13,89 \%$ & $5,56 \%$ \\
\hline
\end{tabular}


Tabel 17 Menunjukkan bahwa sebagian besar status lahan dari petani responden di Desa Tonsewer adalah milik sendiri dengan rata-rata luas lahan $3.830 \mathrm{~m} 2$ dan petani yang memiliki lahan milik sendiri 80,55 persen, lahan sewa 13,89 persen serta lahan garap sebesar 5,56 persen. Berdasarkan hasil penelitian lahan usahatani di Desa Tonsewer baik milik sendiri maupun sewa dan bagi hasil sudah berorientasi profit sehingga di masukan pada kategori komersial.

Perubahan Input Lahan di Desa Tonsewer dapat di lihat berdasarkan kriteria sebagai berikut :

Input $<35 \%$ (Subsisten)

$35 \%-65 \%$ (Semi komersial)

$>65 \%$ (Komersial)

Berdasarkan kriteria tersebut, maka input lahan di Desa Tonsewer tergolong dalam petani komersial.

2. Tenaga Kerja

Tenaga kerja yang digunakan oleh petani responden di desa tonsewer dapat di bagi menjadi dua yaitu, tenaga kerja dalam keluarga yaitu Bapak,Ibu, Anak. Dan tenaga kerja luar keluarga yakni tenaga kerja dengan sistim upahan. Rincian tentang Input Tenaga Kerja dapat di lihat pada Tabel 18.

Tabel 18. Input Tenaga Kerja

\begin{tabular}{c|c|c|c}
\hline $\begin{array}{c}\text { Rata-rata } \\
\text { Tenaga Kerja } \\
\text { Dalam } \\
\text { Keluarga }\end{array}$ & $\begin{array}{c}\text { Rata-rata } \\
\text { Tenaga Kerja } \\
\text { Luar } \\
\text { Keluarga }\end{array}$ & $\begin{array}{c}\text { Tenaga } \\
\text { Kerja } \\
\text { Dalam } \\
\text { Keluarga }\end{array}$ & $\begin{array}{c}\text { Tenaga } \\
\text { Kerja } \\
\text { Luar } \\
\text { Keluarga }\end{array}$ \\
\hline 2 & 6 & $23,85 \%$ & $76,14 \%$ \\
\hline
\end{tabular}

Tabel 18, menunjukkan bahwa Ratarata tenaga kerja dalam keluarga yang di gunakan oleh petani responden berjumlah 2 orang dan rata-rata tenaga kerja di luar keluarga adalah 6 orang, Tenaga Kerja dalam keluarga sebesar 23,85 persen dan tenaga kerja di luar keluarga 76,14 persen. Tenaga kerja dalam keluarga meskipun tenaga kerja sendiri, tapi di dedikasikan untuk usaha bisnis, sedangkan tenaga kerja sewa/bagi hasil sudah komersial karena mengupah tenaga kerja dari luar keluarga untuk usaha bisnis.
Input tenaga kerja di Desa Tonsewer dapat di lihat berdasarkan kriteria sebagai berikut :

Input $<35 \%$ (Subsisten)

$35 \%-65 \%$ (Semi komersial)

$>65 \%$ (Komersial)

Berdasarkan kriteria yang di telah uraikan di atas, dapat di lihat bahwa input tenaga kerja di Desa Tonsewer tergolong dalam petani komersial.

\section{Modal}

Sumber modal petani responden bersumber dari modal sendiri (simpanan atau tabungan hasil usaha tani), dan modal pinjaman (bank, tetangga, saudara dll).

Petani di Desa Tonsewer menggunakan modal milik sendiri untuk bisnis usahatani, begitu juga dengan modal yang di pinjam oleh petani digunakan untuk bisnis usahatani mereka. Output Modal dapat di lihat pada Table 19.

Tabel 19. Input Modal

\begin{tabular}{cc}
\hline Modal Sendiri & Modal Pinjaman \\
\hline $80,14 \%$ & $19,85 \%$ \\
\hline
\end{tabular}

Tabel 19 menjelaskan bahwa, modal milik sendiri 80,14 persen, dan modal pinjaman sebesar 19,85 persen.

Input Modal di Desa Tonsewer dapat di lihat berdasarkan kriteria sebagai berikut :

Input $<35 \%$ dibeli (Subsisten)

35\%-65\% dibeli (Semi komersial)

$>65 \%$ dibeli (Komersial)

Berdasarkan kriteria tersebut, maka input modal di Desa Tonsewer tergolong dalam petani subsisten.

\section{Output Berusahatani (Presentase Output Usahatani yang di Jual di Konsumsi dan di Simpan) \\ Desa Tonsewer memiliki banyak} golongan gereja sehingga masyarakatnya lebih terbuka untuk keberagaman. Dan juga memiliki akses pasar yang terbuka sehingga memudahkan para petani untuk menjual hasil usahatani mereka. Hasil panen petani di Desa Tonsewer, ada yang di jual, ada yang di konsumsi dan disimpan. Hasil usaha tani di jual ke pedagang perantara atau pengecer, pedagang 
atau pengecer umumnya berasal dari Desa Tonsewer dan Tompaso, lokasi pasar pengecer biasanya ada di pasar tradisional yang berada di pasar Tompaso, Kawangkoan, dan Langowan, Dari hasil komoditi pertanian yang di jual, ada juga yang di konsumsi untuk kebutuhan rumah tangga dan di simpan untuk di jadikan benih kecuali komoditi tomat. Output usahahatani yang di Jual, di konsumsi dan di simpan dapat di lihat pada Tabel 20.

Tabel 20. Output Usahatani yang di Jual, di Konsumsi dan di Simpan

\begin{tabular}{cc}
\hline Di Jual & Di Konsumsi \\
\hline $80,10 \%$ & $1,2 \%$ \\
\hline
\end{tabular}

Hasil penelitian pada tabel 20, menunjukkan bahwa Output usahatani yang di jual adalah 80.10 persen, di konsumsi 1,2 persen dan output usahatani yang di simpan sebesar 19,48 persen.

Output Berusahatani di Desa Tonsewer dapat di lihat berdasarkan kriteria sebagai berikut :

Output $<35 \%$ dijual (Subsisten)

$35 \%-65 \%$ dijual (Semi komersial)

$>65 \%$ dijual (Komersial)

Berdasarkan kriteria yang di telah uraikan di atas, dapat di lihat bahwa output usahatani yang di jual tergolong dalam petani komersial.

\section{Rekapitulasi Input dan Output Berdasarkan Kriteria Usahatani di Desa Tonsewer.}

Tabel 21. Rekapitulasi Input dan Output Berdasarkan Kriteria Usahatani di Desa Tonsewer

\begin{tabular}{cc}
\hline Input & Kriteria Usahatani \\
Lahan & Petani Komersial \\
Tenaga Kerja & Petani Komersial \\
Modal & Petani subsisten \\
\hline
\end{tabular}

Tabel 22. Rekapitulasi Input dan Output Berdasarkan Kriteria Usahatani di Desa Tonsewer

\begin{tabular}{cc}
\hline Output & Kriteria Usahatani \\
\hline Usahatani yang di jual & Petani Komersial \\
\hline
\end{tabular}

Kesimpulan

Hasil penelitian Orientasi Usahatani di Desa Tonsewer kecamatan Tompaso Barat Kabupaten Minahasa dapat di simpulkan bahwa, petani di Desa Tonsewer sudah berorientasi komersial dengan tingkatan yang berbeda-beda tapi penulis tidak meneliti derajat tingkatan itu karena untuk meneliti derajat tingkatan itu perlu kriteria lain yaitu seperti apa derajat komersialisasi, penelitian ini hanya melihat dari beberapa kriteria input dan output.

\section{Saran}

Orientasi Usahatani di Desa Tonsewer perlu mendapat dukungan oleh pemerintah dalam hal ini instansi yang terkait untuk modal usaha yang merupakan input usahatani di Desa Tonsewer masih termasuk dalam input usahatani subsisten.

\section{DAFTAR PUSTAKA}

Badan Pusat Statistik Kabupaten Minahasa Utara. (2017). https: // minutkab .bps. go. id/. Diakses 21 April 2018.

Cresswel, J. (2013). Penelitian Kualitatif dan Design Riset. Memilih di Antara Lima Pendekatan. Yogyakarta: Pustaka Pelajar.

Harsono, B. (2003). Hukum Agraria Indonesia (Hukum Tanah Nasional).

Munif A. 2011. Perlindungan Hukum Terhadap Hak-Hak Rakyat Atas Tanah

Nugroho, I. d. (2004). Pembangunan Wilayah, Perspektif Ekonomi, Sosial dan Lingkungan. Jakarta: LP3ES.

Pemerintah Republik Indonesia. (2006). Peraturan Presiden Repulik Indonesia No 65 Tahun 2006. Perubahan Atas Peraturan Presiden Nomor 36 Tahun 2005 Tentang Pengadaan Tanah Bagi Pelaksanaan Pembangunan Untuk Kepentingan Umum. Jakarta.

Rustiadi, S. (2011). Perencanaan dan Pengembangan Wilayah. Jakarta: 
Crestpent Press dan Yayasan Pustaka Obor Indonesia.

Sirojuzilam, M. (2010). Regional: pembangunan, perencanaan dan ekonomi. Medan: USU Press.

Soimin S. 2001. Status Hak dan Pembebasan Tanah. Edisi Kedua. Jakarta: Sinar Grafika.

Sumardjono, M. (2015). Dinamika Pengaturan Pengadaan Tanah di Indonesia .

Tarigan. (2012). Perencanaan Pembangunan Wilayah. Jakarta: Bumi Aksara.

UU No 2 Tahun 2012. Pengadaan Tanah Bagi Pembangunan Untuk Kepentingan Umum. Http: // www. bpn. go. id/ PUBLIKASI/ Peraturan-Perundangan/ Undang-Undang/ undang - undang nomor - 2 - tahun - 2012 - 876 . Diakses 21 April 2018.

Warokka TD, Zulkifli, Simaniburuk M. 2006. Sengketa Tanah: Bentuk. 